\title{
Compounding of Spent Nuclear Fuel
}

Tatyana A. Kulagina ${ }^{a}$, Vladimir A. Kulagin*a and Vladislav A. Popkova, ${ }^{a}$ Siberian Federal University 79 Svobodny, Krasnoyarsk, 660041, Russia ${ }^{b}$ Radiochemical plant of Mining and Chemical Combine 53 Lenina Str., Zheleznogorsk, 662970, Russia

Received 22.12.2015, received in revised form 19.01.2016, accepted 20.02.2016

The paper resents the results of the research into the processes of extraction of liquid radioactive waste of low and intermediate activity levels from storage and their hardening into inorganic binders (cementation process). The resulting cementing product has a number of advantages: it has high mechanical strength, is non-combustible, radiationally and chemically resistant, and has reduced external radiation of cementitious materials due to high density. Cementation as a technology of conditioning of liquid radioactive waste is a process of immobilization of liquid radioactive waste in cement matrix to obtain a solid final product (cement compound). The paper shows the expediency of using the effects of cavitation technology which is quite easily feasible, energy-efficient, and in some cases has no alternative. The disposal of radiochemical production waste with the decommissioning of nuclear power plants on the basis of cavitation technology increases the productivity of their extraction and the strength of cement compound.

Keywords: cement compound, cavitation technology, dissolution of lumpy sludge of nuclear fuel waste, track detector.

Citation: Kulagina T.A., Kulagin V.A., Popkov V.A. Compounding of spent nuclear fuel, J. Sib. Fed. Univ. Eng. technol., 2016, 9(2), 280-295, DOI: 10.17516/1999-494X-2016-9-2-280-295.

(c) Siberian Federal University. All rights reserved

* Corresponding author E-mail address: v.a.kulagin@mail.ru 


\title{
Компаундирование
}

\section{отработавшего ядерного топлива}

\author{
Т.А. Кулагина ${ }^{a}$, В.А. Кулагин ${ }^{a}$, В.А. Попков ${ }^{a, 0}$ \\ ${ }^{a}$ Сибирский федеральный университет \\ Россия, 660041, Красноярск, Свободный, 79 \\ ${ }^{\circ}$ Радиохимический завод Горно-химического комбината \\ Россия, 662970, Железногорск, Ленина, 53
}

\begin{abstract}
Изложены результаты исследований процессов извлечения из хранилищ и отверждения жидких радиоактивных отходов низкого и среднего уровней активности в неорганические вяжущие (процесс иементирования). Образующийся при иементировании продукт обладает цельм рядом достоинств: имеет высокую механическую прочность, является негорючим, радиационно и химически устойчив, понижено внешнее излучение иементных материалов из-за высокой плотности. Цементирование как технология кондиционирования жидких радиоактивных отходов представляет собой процесс иммобилизации жидких радиоактивных отходов в иементную матрииу с получением твёрдого конечного продукта (иементного компаунда). Показана иелесообразность использования эффектов кавитаиионной технологии, достаточно легко реализуемой, энергоэффективной и в ряде случаев не имеющей альтернативы. Утилизачия отходов радиохимического производства при выводе из эксплуатации ядерных энергетических установок на базе кавитационной технологии приводит $\kappa$ повышению производительности их извлечения и прочности цементного компаунда.
\end{abstract}

Ключевые слова: чементный компаунд, кавитационная технология, растворение твердых осадков отходов ядерного топлива, трековый детектор.

\section{Introduction}

The importance of the work is determined by the need to develop a new effective and high technology to manage spent nuclear fuel including the deletion of a harmful effect on the environment in conditions of the long-term storage.

In accordance with the International Convention on the Safety of Radioactive Waste Management, the effective means of the protection of individuals, society in general and the environment from the harmful effect of radionuclides and ionizing

radiation should be provided both now and in future $[1,4,6,13,14,16,18]$. Although the amount of radioactive wastes compared to other anthropogenic waste is negligible (approximately $0.5 \%$ of all industrial waste), their specificity requires the improvement and development of new management technologies and the use of special methods to ensure safety for man and the biosphere. From the standpoint of the long-term safety, the most important stage of radioactive waste management is their long-term storage and disposal.

Russia has created its own legal and institutional system of support and regulation of nuclear and radiation safety $[4,13,17,19]$. A brief review of the methods of radioactive waste management is given in [20].

Currently the most widely used hardening process of liquid radioactive waste of low and intermediate activity levels is the inclusion of liquid radioactive waste (LRW) in inorganic binders (cementation process). The resulting cementing product has a number of advantages: high mechanical

$$
-281-
$$


strength, it is not flammable, radioationally and chemically resistant, low external radiation of cementitious materials due to high density.

Increased security requirements of storage of the waste derived from the reprocessing of spent nuclear fuel (SNF) lead to the need for fundamentally different scientific technologies, in particular, the effects of cavitation technology that is quite easily feasible, energy-efficient, and in some cases having no alternative.

A physical model of cavitation hydrothermodynamic effect can be represented by two main mechanisms: the transmission of shock waves near the collapsing cavitation microbubbles and the impact of cumulative microjets with their asymmetric collapse. In this case the field of high temperatures (up to $15,000^{\circ} \mathrm{C}$ ) and pressures (up to 10,000 atm.) are realized. The speed of cumulative jets can rise up to $500 \mathrm{~m} / \mathrm{s}$. The phenomenon is accompanied by intensive turbulent micro mixing and mechanothermolysis of water with the generation of $\mathrm{H}_{2}, \mathrm{O}_{2}, \mathrm{H}_{2} \mathrm{O}_{2}$ and free hydrogen bonds and some more. Thus, the local area near a collapsing cavitation microbubble is a unique reactor for various reactions and technological processes carried out under normal ambient physical conditions [2, 3, 5].

There are several forms and layers of waste, which are heterogeneous in all the phases of the technological process, wherein there are three major forms [10]:

liquid which consists of water, dissolved salts and other chemicals and is located above dense layers, or between them, sometimes immersing in salt precipitate;

salt precipitate that is crystallized salt waste generated over the sludge, which is mainly watersoluble;

sludge (pulp) is a dense water-insoluble component, which is deposited on the bottom of the tank forming a thick layer of variable consistency.

At present, the enterprises of the nuclear energy cycle around the world are having trouble processing high-level waste accumulated over the past half century. Experience has shown that the long-term storage of active liquid waste leads to the accumulation of solid sludge or pulp. This form of waste is the most difficult in terms of recycling and disposal, which determines the need to address a number of technological challenges, including:

evaluation of the effect of temperature on the kinetics of physical and chemical processes in hardening cement mass and ultimately on the quality of obtained concrete;

determination of the effect of physical and chemical properties of cavitationally treated water on the quality of cement compound.

\section{Numerical study of the temperature field}

\section{in a standard 200-liter barrel container for spent nuclear fuel storage}

Let us consider the results of the studies of the temperature field in a standard 200-liter barrel for the three different processes: cooling of water and cement compound, heat release of radioactive decay of radionuclides in cement compound, cement compound hardening.

The objective of this thermal calculation is to determine the temperature field in a barrel of cement compound in the process of its hardening and subsequent storage. These processes can be described on the basis of the following reasons: first, the process of cement compound hardening in a barrel in the present time slot is a disequilibrium process from the viewpoint of heat transfer, since the temperature field in it continuously varies over time due to heat generation during the reaction of cement harden- 
ing. Secondly, the process of heat exchange with the environment is transient due to the continuous temperature change of heat transfer surface. Thirdly, the process of the heat transfer of a barrel with the environment during the prolonged keeping of the barrel in storage is steady due to the release of heat during the radioactive decay of radionuclides contained in the cement compound.

For calculation of the coefficient of heat transfer from the wall to the environment we used a criterial equation describing heat transfer in free convection conditions [15]:

$$
\mathrm{Nu}=0,135(\mathrm{Gr} \cdot \mathrm{Pr})^{0.33},
$$

where $\mathrm{Nu}$ is Nu.sselt number; $\mathrm{Gr}$ is Grashof criterion; Pr is Prandtl number.

The material in the barrel is water or cement compound, the environment is air. The calculation of the equation (1) gives the values of $\alpha=6-7 \mathrm{~W} / \mathrm{m} 2 \cdot \mathrm{K}$ for differences in the wall and environment temperatures from 5 to 50 degrees, which makes it constant throughout the entire process of the heat exchange of the barrel with the environment. There is a cylinder of $R$ radius and $H=2 l$ height, the temperature of which is $T_{0}$. At the initial time it is placed in the environment with constant temperature $T_{c}>T_{0}$. The task is to find the temperature distribution at any time provided there is a symmetrical task according to Fig. 1.

The heat conduction equation is transformed into:

$$
\begin{aligned}
& \frac{\partial T(r, z, \tau)}{\partial \tau}=a\left(\frac{\partial^{2} T(r, z, \tau)}{\partial r^{2}}+\frac{1}{r} \frac{\partial T(r, z, \tau)}{\partial r}+\frac{\partial^{2} T(r, z, \tau)}{\partial^{2} z}\right), \\
& \tau>0 ; 0<r<R ;-l<z<-l .
\end{aligned}
$$

where $r, z, \tau$ are cylindrical coordinates. The initial and boundary conditions are:

$$
\begin{aligned}
& T(r, z, 0)=T_{0}=\text { const; } \\
& -\frac{\partial T(R, z, \tau)}{\partial r}+\frac{\alpha}{\lambda}\left[T_{c}-T(r, z, \tau)\right]=0 \\
& \frac{\partial T(0, z, \tau)}{\partial r}=0, \quad T(0, z, \tau) \neq \infty \\
& -\frac{\partial T(r, l, \tau)}{\partial z}+\frac{\alpha}{\lambda}\left[T_{c}-T(r, l, \tau)\right]=0 ; \\
& \frac{\partial T(r, 0, \tau)}{\partial z}=0 .
\end{aligned}
$$

The solution of this equation has the form of

$$
1-\theta=\frac{T_{c}-T(r, z, \tau)}{T_{c}-T_{0}}=\sum_{n=1}^{\infty} \sum_{m=1}^{\infty} A_{n, 1} A_{m, 2} J_{0}\left(\mu_{n, 1} \frac{r}{R}\right) \cos \mu_{m, 2} \frac{z}{l} \exp \left[-\left(\frac{\mu_{n, 1}^{2}}{R^{2}}+\frac{\mu_{m, 2}^{2}}{l^{2}}\right) a \tau,\right.
$$

where $A_{n,}, A_{m, 2}$ are constant coefficients determined by the formulas:

$$
A_{n, 1}=\frac{2 B i_{1}}{J_{0}\left(\mu_{n, 1}\right)\left(\mu_{n, 1}^{2}+\mathrm{Bi}_{1}^{2}\right)} ; \quad A_{m, 2}=(-1)^{m+1} \frac{2 B i_{2} \sqrt{\mathrm{Bi}_{2}^{2}+\mu_{m, 2}^{2}}}{\mu_{m, 2}\left(\mathrm{Bi}_{2}^{2}+\mu_{m, 2}^{2}+\mathrm{Bi}_{2}\right)}
$$


where $\mu_{n, 1}, \mu_{m, 2}$ are the roots of the corresponding characteristic equations; $J_{0}$ is the Bessel function of zero order; $B_{i 1}, B_{i 2}$ are Biot criteria equal to $\alpha 1 / \lambda$ and $\alpha R / \lambda$, respectively.

There are no ready mathematical solutions of the heat conduction equation, taking into account the conditions of cement compound hardening in a barrel in the literature. The offered mathematical model, which allows calculating the temperature distribution in a tank of a cylindrical shape when cement compound hardens in it, takes into account the kinetics of heat generation processes, the redistribution of heat due to heat conduction and radiation heat loss.

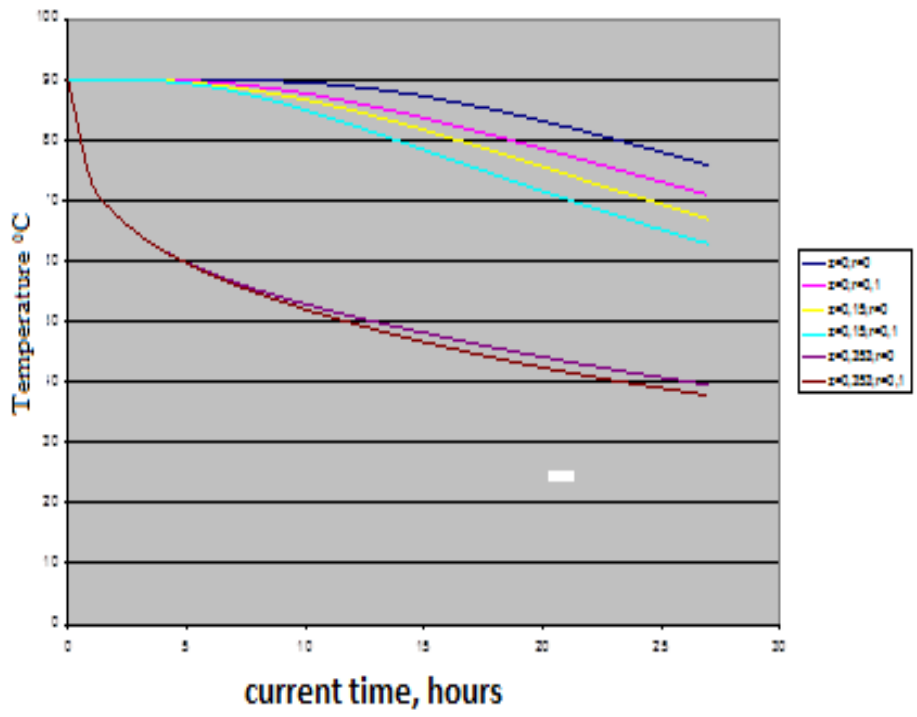

$a$

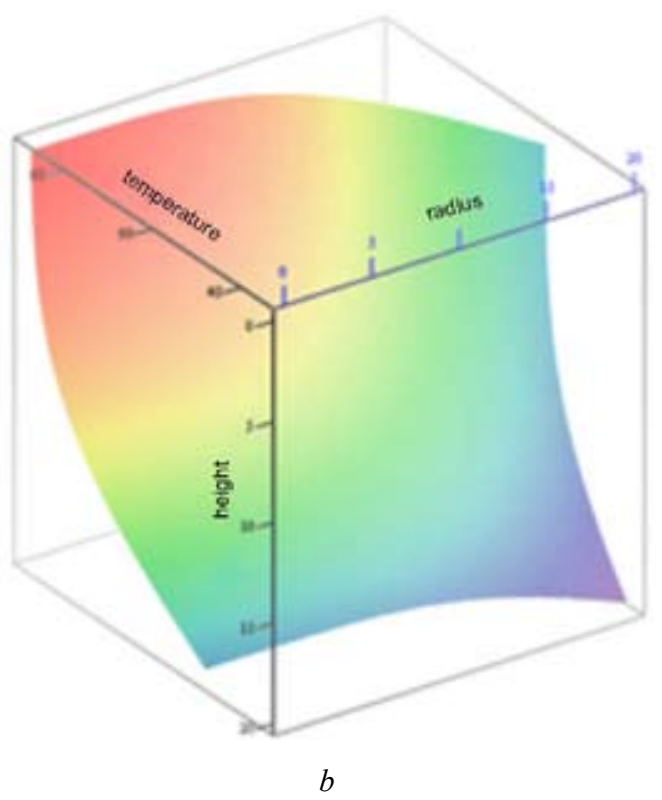

Fig. 1 a) time dependences of the temperature in different parts of the barrel in the process of cooling water, b) the temperature profile in various sections of the barrel 10 hours after cooling water therein 
The equation for the temperature in this computing experiment is as follows:

$$
S \frac{\mathrm{d} T}{\mathrm{~d} t}=\alpha\left(T_{0}-T\right)+J
$$

where $S$ denotes the heat capacity of the calorimeter, $\alpha$ denotes the heat transfer coefficient, and $T_{0}$ denotes the external temperature. The value $J$ describes the intensity of heat generation. For the same type of exothermic reactions, the heat transfer equation is closed with a kinetic equation of the following form

$$
Q \frac{\mathrm{d} C}{\mathrm{~d} t}=-J(C, T)
$$

where $C$ is the number of substances capable of reacting, and $Q$ is the amount of heat generated by the introduction into the reaction of one unit $C$. The intensity $J / Q$, at which the reaction occurs, depends on the amount of the potential reactant and temperature.

To complete the mathematical formulation of the task, the heat intensity $J(C, T)$ in the equations (10) and (11) as a function of $C$ and $T$, is given in the form of a kinetic equation describing the cumulative reaction of cement compound hardening:

$$
J=C_{0} \beta\left(\frac{C}{C_{0}}\right)^{n} \exp \left(\frac{\gamma T}{273^{\circ}\left(T+273^{\circ}\right)}\right),
$$

where $C_{0}$ is initial cement content in the system, and $n, \beta$ and $\gamma$ are free parameters to be chosen so that the theoretical (numerical) solution $T(t)$ of the system of equations (10) and (11) with the corresponding initial conditions as much as possible coincides with the temperature versus time measured in the experiment.

The system of equations for the processes of the redistribution of heat in cylindrical coordinates can be written as [15]:

$$
\left\{\begin{array}{c}
c_{v} \frac{\partial T}{\partial t}=\frac{1}{r} \frac{\partial}{\partial r}\left(\lambda \cdot r\left(\frac{\partial T}{\partial r}\right)\right)+\frac{1}{r^{2}} \frac{\partial}{\partial \mathrm{f}}\left(\lambda \frac{\partial T}{\partial f}\right)+\frac{\partial}{\partial z}\left(\lambda \frac{\partial T}{\partial z}\right)+J(C, T) \\
Q \frac{\partial C}{\partial t}=-J(C, T)
\end{array}\right.
$$

where $\lambda$ is thermal conductivity, variable $C$ and heat capacity $c_{v}$ here refer to unit volume, and $J$ again requires a formula (12). Without enduring thermal conductivity out of the signs of partial derivatives, we create an opportunity to consider the physical coefficients of the system to be variables according to the spatial coordinates: separate ones for cement compound, for steel walls of the barrel and for the air under the cover.

As it has been previously defined, the steel surface of the barrel presents the boundary conditions of the 3rd kind, namely,

$$
-\lambda \frac{\partial T}{\partial n}=\alpha\left(T-T_{0}\right)
$$

where $T_{0}$ is the ambient temperature, $\alpha$ is the coefficient of steel heat transfer into the air. 
Comparing the course of cooling water and cement compound, we can conclude that both processes are described by the same degree dependences, but cement compound cools much faster water due to the difference in thermal characteristics. Based on the temperature profiles in the various sections of the barrel shown in Fig. $1 a$ and $b$, the cooling process is characterized by substantial temperature gradients between the central points and points on the surface of the heat removal, and the thermal characteristics of the barrel content limit the process of heat removal.

Based on the results presented in Fig. 2, it can be stated that the internal volume of the barrel heats up to the temperatures of $70{ }^{\circ} \mathrm{C}$ or more, which in practice was noted earlier. Overheating of

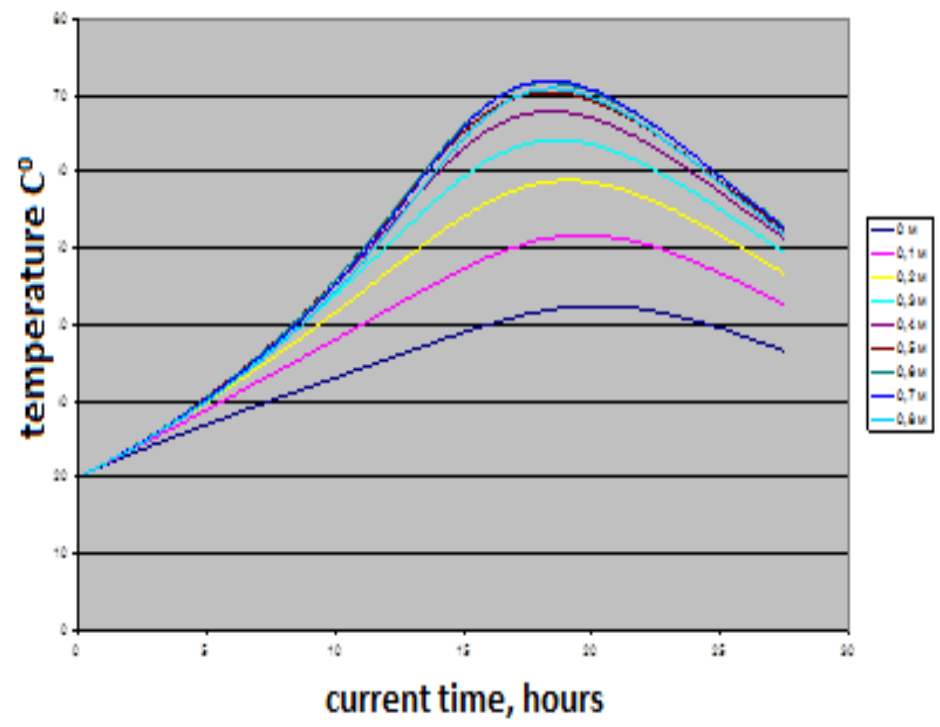

$a$

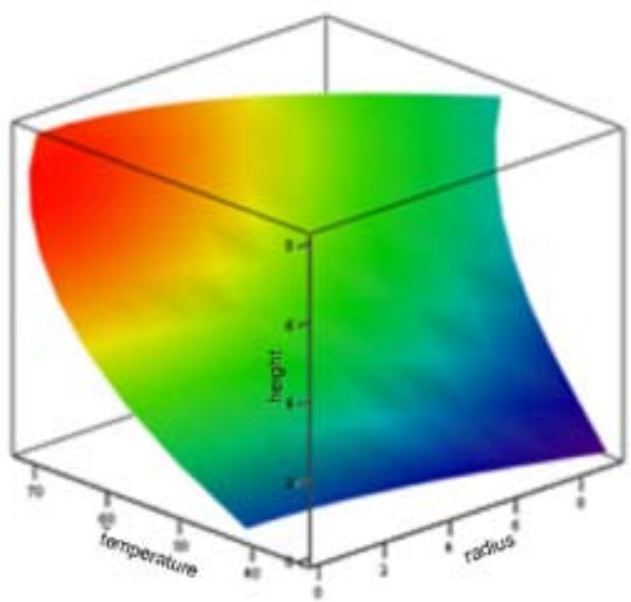

$b$

Fig. 2 a) time dependences of the temperature in different parts of the barrel in the process of cement compound hardening, b) the temperature profile in various sections of the barrel 18 hours after cement compound hardening therein 
the central parts against peripheral ones is $25-30{ }^{\circ} \mathrm{C}$, which once again demonstrates the need for measures to reduce the magnitude of this overheating to ensure the uniformity and the quality of cement compound.

\section{Research Methods and Experimental Technique}

In accordance with the program of experimental work on the selection of the composition of cement compound and cementation technological conditions to prepare the cement compound we used:

- portland cement of TSEM I 42,5B (ЦЕM I 42,5Б) grade, GOST 31108-2003 (PTS 500-D0 (ПЦ 500-Д0) for the previous classification), "Mordovtsement” Jsc.;

- sorption additive - powder clinoptilolite of Kholinskii deposit TU (TY) 2163-002-12763074 with the following fractional composition ( $\%$ by weight): more than $1 \mathrm{~mm}-2.55$; up to $0.5 \mathrm{~mm}-13.74$; up to $0.25 \mathrm{~mm}-12.20$; up to $0.125 \mathrm{~mm}-34.19$; up to $0.1 \mathrm{~mm}-15.23$; up to $0.05 \mathrm{~mm}-20.03$; less than $0.05 \mathrm{~mm}-2.06$;

- water from PPR fiber (technical) and water after cavitation impact (Table 1);

- insoluble sludge of hydroxide pulp.

The composition of the cement slurry was adjusted after a test batch using binding components got for test operations and determination of the spreadability of cement mortar. To determine the spreadability of the cement compound we used Viscometer Suttarda (VS) according to GOST 2378979 "Binding Gypsum. Testing methods".

When preparing the samples we used the following scheme of component mixing: clinoptilolite with hydroxide pulp was loaded into plastic cups in a predetermined ratio and was mixed. After 15 minutes, we added a calculated amount of cement and water, and thoroughly stirred the mixture. The resulting mixture was placed into the molds specially made of PTFE to form samples with a diameter and a height of $20 \mathrm{~mm}$. By lightly tapping the mold body for several minutes, the mixture was compacted and the air was removed therefrom. Thereafter the molds with the samples were placed for 24 hours in a normal hardening chamber, provided relative air humidity of $95 \pm 5 \%$ at a temperature of 20-30 ${ }^{\circ} \mathrm{C}$. After one day, the samples were removed from the molds and placed back into the normal hardening chamber for 28 days. After aging the samples were tested for mechanical strength, resistance to water and frost. To ensure comparability and reliability of the results, the characteristics of the samples were determined according to the three experiments.

Table. 1. Physical and chemical properties of water after cavitation treatment with different volumes of filling with supercavitation reactor (SC-reactor)

\begin{tabular}{|c|c|c|c|c|c|c|c|c|c|c|}
\hline \multirow{2}{*}{$\begin{array}{l}\text { Volume of filling } \\
\text { of SC-reactor } V, \%\end{array}$} & \multicolumn{2}{|c|}{$T,{ }^{\circ} \mathrm{C}$} & \multicolumn{2}{|c|}{$\begin{array}{c}\text { DOC }^{*}, \% \text { of } \\
\text { saturation }\end{array}$} & \multicolumn{2}{|c|}{$x, \mathrm{Ohm}^{-1} / \mathrm{cm}$} & \multicolumn{2}{|c|}{$\mathrm{pH}$} & \multicolumn{2}{|c|}{$E, \mathrm{mV}$} \\
\hline & $\alpha=10^{\circ}$ & $\alpha=20^{\circ}$ & $\alpha=10^{\circ}$ & $\alpha=20^{\circ}$ & $\alpha=10^{\circ}$ & $\alpha=20^{\circ}$ & $\alpha=10^{\circ}$ & $\alpha=20^{\circ}$ & $\alpha=10^{\circ}$ & $\alpha=20^{\circ}$ \\
\hline $\begin{array}{l}\text { Properties of water } \\
\text { before treatment }\end{array}$ & \multicolumn{2}{|c|}{20,7} & \multicolumn{2}{|c|}{101,2} & \multicolumn{2}{|c|}{0} & \multicolumn{2}{|c|}{5,4} & \multicolumn{2}{|c|}{200} \\
\hline $100^{\prime}$ & 40,5 & 32,6 & 85,1 & 96,65 & 14,5 & 6 & 5,65 & 5,45 & 133 & 168,5 \\
\hline 65 & 34,6 & 27,2 & 87,65 & 95,7 & 5,5 & 13 & 6,0 & 5,7 & 128,5 & 147 \\
\hline
\end{tabular}

* DOC - dissolved oxygen concentration 
The auxiliary and measuring equipment made it possible to study the effect of hydrodynamic cavitation on the following parameters of water condition: temperature; dissolved oxygen concentration (DOC); $\mathrm{pH}$; electrical conductivity; oxidation-reduction potential (ORP), and others. The experimental results of the changes of these characteristics of distilled water after cavitation treatment with a constant number of cavitation $\chi=0.05$ and the methods of the regression analysis allowed setting the rational duration of the cavitation treatment.

ORP dependence on the time of cavitation effect is exponential:

$$
\begin{aligned}
& y=15,34 \exp (-x / 106,36)+15,34 \exp (-x / 106,39)+ \\
& +149,24 \exp (-x / 21,28)+141,43
\end{aligned}
$$

and with a value of 150 seconds reaches a plateau that allows selecting the area of the most intense change of ORP - 30-90 sec.

When there is a cavitation effect on water during this time, ORP is reduced by $43 \%$, whereas the maximum decrease of ORP is $47 \%$. It means the rate of change of ORP during the cavitation effect in the range of $30-90 \mathrm{sec}$. is almost three times greater than the rate of change of ORP when the effect is in the range of 90-300 sec.

\section{The use of cavitation technology to extract the pulp \\ from the storage of spent nuclear fuel}

The studies were conducted using several samples of partially soluble hydroalumosilicate solid phase [7]. In order to treat the pulp at an elevated temperature we used a thermostat that allows maintaining the desired temperature of the working mixture with an error of not more than $3{ }^{\circ} \mathrm{C}$. The work solutions were prepared from the chemicals of such marks as "Ch" ("Y") and "Kh.Ch" ("X.Ч."). The measurement of the volume of the solid and liquid phases was carried out after settling suspensions within 24 hours. In the cases when the liquid phase was not clarified for the period, settling time was increased or the solution was filtered through a paper filter named "blue ribbon". The selection of the liquid phase for an analysis was carried out by decantation.

The experimental results (Table 2) showed that the yield of pulp components in the solution according to the conventional technology (Experiment 1) reaches 35,6 for $\mathrm{Al}, 34,39 \%$ for $\mathrm{SiO}_{2}$, whereas with the use of cavitationally treated water (Experiment 2 ) the values were $56.03 \%$ and $60.72 \%$ respectively.

These experiments suggest that the use of the cavitation technology for erosion and dissolution of the solid phase of model pulp can improve the efficiency of processing of highly radioactive waste and releasing of containers from accumulated sludge for their storage without increasing concentrations of chemicals and temperature increase, which in turn reduces the corrosion load [7, 8, 15].

In the course of the works the time (for various conditions it is in the range from 100 to 500 hours or more) and the degree of relaxation of the modified properties of water were determined, which allows using such water as a carrier phase for the preparation of solutions in the processing of the main components of the pulp of SNF. We defined the connections between the transformation of sparingly soluble deposits and time, speed and the values of the cavitation of water and aqueous solutions treatment. 
Table 2. The distribution of components of the aluminosilicate layer of the solid phase between the solutions used for its processing

\begin{tabular}{|l|c|c|c|c|}
\hline \multirow{2}{*}{$\begin{array}{c}\text { Composition of solutions used } \\
\text { for pulp processing }\end{array}$} & \multicolumn{2}{c|}{$\begin{array}{c}\text { Degree of transition into } \\
\text { solution, \% (Experiment 1) }\end{array}$} & \multicolumn{2}{c|}{$\begin{array}{c}\text { Degree of transition into } \\
\text { solution, \% (Experiment 2) }\end{array}$} \\
\cline { 2 - 5 } & $\mathrm{Al}$ & $\mathrm{SiO}_{2}$ & $\mathrm{Al}$ & $\mathrm{SiO}_{2}$ \\
\hline $100 \mathrm{~g} / \mathrm{l} \mathrm{NaOH}$ & 2,52 & 1,81 & 5,79 & 4,34 \\
\hline $\mathrm{H}_{2} \mathrm{O}$ & 2,04 & 0,70 & 2,36 & 0,85 \\
\hline $\mathrm{HNO}_{3}+\mathrm{RCI}$ (relative coordination index) & 1,39 & 8,57 & 2,50 & 15,43 \\
\hline $\mathrm{H}_{2} \mathrm{O}$ & 0,56 & 0,57 & 0,64 & 0,64 \\
\hline $100 \mathrm{~g} / 1 \mathrm{NaOH}$ & 8,88 & 2,74 & 16,87 & 6,30 \\
\hline $\mathrm{H}_{2} \mathrm{O}$ & 5,54 & 0,94 & 6,34 & 1,15 \\
\hline $\mathrm{HNO}_{3}+\mathrm{RCI}$ & 1,22 & 8,65 & 2,01 & 14,96 \\
\hline $\mathrm{H}_{2} \mathrm{O}$ & 0,32 & 1,01 & 0,36 & 1,14 \\
\hline $100 \mathrm{~g} / 1 \mathrm{NaOH}$ & 4,72 & 2,57 & 9,48 & 5,04 \\
\hline $\mathrm{H}_{2} \mathrm{O}$ & 6,60 & 1,28 & 7,34 & 1,68 \\
\hline $\mathrm{HNO}_{3}+\mathrm{RCI}$ & 1,36 & 5,54 & 2,31 & 9,19 \\
\hline $\mathrm{Total}$ & 35,6 & 34,39 & 56,03 & 60,72 \\
\hline
\end{tabular}

\section{The results of the experimental studies on the use of cavitation technology for making cement compound}

For the experimental verification of the theoretical calculations for different models we created a plant for the direct measurement of the temperature field in a barrel, and on the surface of its heat exchange with the environment. In order to measure the temperature we used two types of sensors: chromel-copel thermocouples (TC), and platinum resistance thermometers (RT). Fig. 3 and 4 show the circuit of the arrangement and photographs of two types of sensor units. In order to measure the sensor signals we used standard analog-to-digital converters with an output to a computer. The software of these converters enables to record the measurement results in a convenient form for subsequent processing. To evaluate the thermal characteristics of the barrel, the experiments on the measurement of the temperature field in a barrel in the process of cooling water heated in it up to $90^{\circ} \mathrm{C}$ were carried out by means of a pilot plant.

In this paper, we conducted a series of experiments to determine the effect of cavitation on the physicochemical properties of water subject to a maximum cavitation effect, i.e., at the minimum cavitation. Fig. 6 shows the results of the experimental measurements of the temperatures during cement compound hardening for the three points: at the hottest point inside the barrel TC3 (see Fig. 3), at a peripheral point TC6 and on the side surface of the barrel at a point RT3 at different values of water-binder ratio. For all these points we present the theoretical dependences.

The greatest agreement between the calculation and the experiment (Fig. 5) is observed for $\mathrm{W} / \mathrm{B}=0.6$, where the maximum temperatures differ by 6 degrees. For $\mathrm{W} / \mathrm{B}=0.45$ the maximum theoretical temperature exceeds the experimental one by $15{ }^{\circ} \mathrm{C}$. The largest difference is observed for the theoretical and experimental temperatures on the side surface of the barrel at the point RT3 that is $40^{\circ}$. Obviously, the model does not take into account the peculiarities of the process of cement compound hardening at the temperature close to the boiling point of water. At the same time, the 


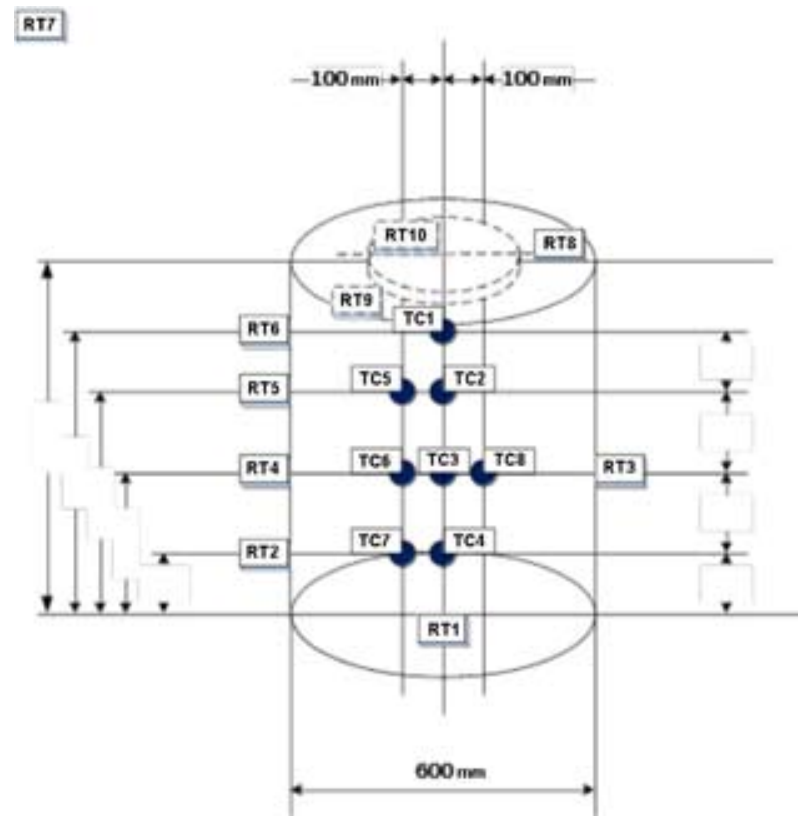

Fig. 3. The circuit of spatial arrangement of sensors in the volume of the container and on its outer surface

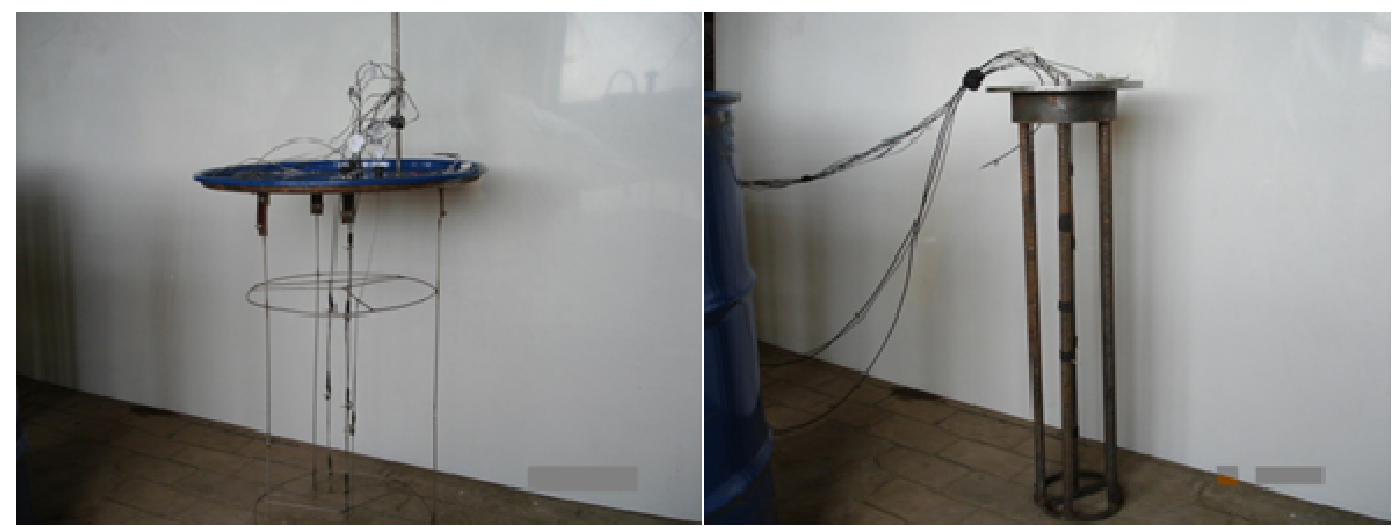

Fig. 4. The sensor unit of the experimental plant for measuring the temperature in the interior of the barrel

thermal calculation of the barrel on the model described above can be used for $\mathrm{B} / \mathrm{B} \geq 0.5$ with sufficient technical calculation accuracy.

The mechanical strength of the samples was determined by the branch instruction "Cement compounds on the basis of radioactive waste". The results of mechanical experiments are presented in Table 3, the freezing tests are in Table 4, the measurements of cesium-137 leach rate are in Table 5.

The results of the measurements of cesium-137 leach rate (using the cavitation technology, Table 5) indicates that it does not exceed the values of the standard rules adopted by the nuclear industry.

Increasing the specific surface area of cement directly in aqueous medium using cavitation dispersing allows better using its potential properties and increasing the degree of hydration and the 


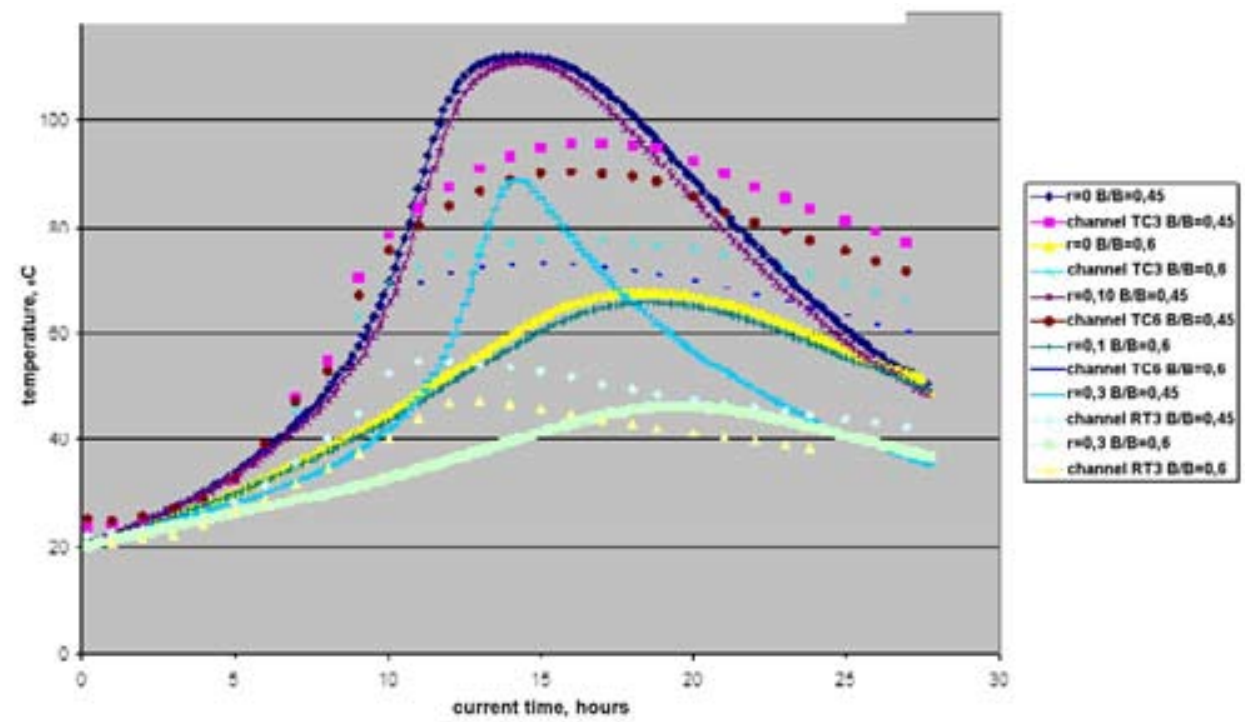

Fig. 5. Comparison of the theoretical and experimentally measured temperatures during the process of cement compound hardening at the hottest point inside the barrel TC3, at the peripheral point TC6 and on the side surface of the barrel at the point RT3 for different values of the water-binder ratio

Table 3. The original mechanical strength of cement compounds

\begin{tabular}{|c|c|c|c|c|c|c|c|c|c|}
\hline \multicolumn{2}{|c|}{ Indicator } & \multicolumn{8}{|c|}{ Mechanical strength of compound after 28 days, $\mathrm{MPa}$} \\
\hline \multirow{2}{*}{$\mathrm{W} / \mathrm{C}$} & \multirow{2}{*}{$\mathrm{W} / \mathrm{B}$} & \multirow{2}{*}{\multicolumn{2}{|c|}{$\begin{array}{l}\text { With industrial } \\
\text { water }\end{array}$}} & \multicolumn{6}{|c|}{ Samples of cavitationally treated water } \\
\hline & & & & \multicolumn{2}{|c|}{ No. 1} & \multicolumn{2}{|c|}{ No. 2} & \multicolumn{2}{|c|}{ No. 3} \\
\hline \multirow{2}{*}{0.5} & \multirow{2}{*}{0.41} & 36,0 & 32,5 & 27,4 & 27,7 & 39,2 & 45,2 & 52,2 & 43,0 \\
\hline & & \multicolumn{2}{|c|}{ Average 34,2} & \multicolumn{2}{|c|}{ Average 27,5} & \multicolumn{2}{|c|}{ Average 42,2} & \multicolumn{2}{|c|}{ Average 47,6} \\
\hline
\end{tabular}

Note: $\mathrm{W} / \mathrm{C}$ - water-cement ratio; $\mathrm{W} / \mathrm{B}$ - water-binder ratio

$\mathrm{W} / \mathrm{B}=\mathrm{W} /(\mathrm{C}+\mathrm{K}$-factor $) \mathrm{K}$-factor is determined by the introduction of a thin core on the relevant regulatory documents.

Table. 4. The results of the tests of cement compound samples

\begin{tabular}{|c|c|c|c|c|c|}
\hline No. & $\begin{array}{l}\text { Initial mechanical } \\
\text { strength of } \\
\text { compound } \\
\text { compression } \\
\mathrm{MPa}\end{array}$ & $\begin{array}{l}\text { Average value, } \\
\qquad \mathrm{MPa}\end{array}$ & $\begin{array}{l}\text { Strength of } \\
\text { compound after } \\
\text { freezing tests, } \\
\mathrm{MPa}\end{array}$ & $\begin{array}{c}\text { Average value, } \\
\qquad \mathrm{MPa}\end{array}$ & $\begin{array}{l}\text { Change of } \\
\text { mechanical } \\
\text { strength, \% }\end{array}$ \\
\hline $0-1$ & 36,0 & \multirow{2}{*}{34,2} & 32,8 & \multirow{2}{*}{29,8} & \multirow{2}{*}{$-12,9$} \\
\hline $0-2$ & 32,5 & & 26,8 & & \\
\hline $1-1$ & 27,4 & \multirow{2}{*}{27,5} & 21,3 & \multirow{2}{*}{21,6} & \multirow{2}{*}{$-21,5$} \\
\hline $1-2$ & 27,7 & & 22,0 & & \\
\hline $2-1$ & 39,2 & \multirow{2}{*}{42,2} & 50,7 & \multirow{2}{*}{42,4} & \multirow{2}{*}{0,5} \\
\hline $2-2$ & 45,2 & & 34,1 & & \\
\hline $3-1$ & 52,2 & \multirow{2}{*}{47,6} & 52,9 & \multirow{2}{*}{48,4} & \multirow{2}{*}{1,7} \\
\hline $3-2$ & 43,0 & & 44,0 & & \\
\hline
\end{tabular}


Table 5. Cesium-137 leach rate

\begin{tabular}{|c|c|c|c|c|c|c|c|c|c|}
\hline \multirow{3}{*}{$\begin{array}{c}\text { Sample } \\
\text { No. }\end{array}$} & \multirow{3}{*}{$A_{0}, \mathrm{~Bq} / \mathrm{g}$} & \multicolumn{8}{|c|}{$R_{n}, \mathrm{~g} /\left(\mathrm{cm}^{2} \mathrm{x}\right.$ day $)$} \\
\hline & & \multicolumn{8}{|c|}{ Number of days } \\
\hline & & 1 & 3 & 7 & 10 & 14 & 21 & 28 & 56 \\
\hline $0-1$ & 5850 & $1,03 \mathrm{E}-2$ & $2,47 \mathrm{E}-3$ & $2,93 \mathrm{E}-4$ & $2,00 \mathrm{E}-4$ & $1,88 \mathrm{E}-4$ & $1,26 \mathrm{E}-4$ & $9,46 \mathrm{E}-5$ & $4,89 \mathrm{E}-5$ \\
\hline $0-2$ & 980 & $9,4 \mathrm{E}-2$ & $2,78 \mathrm{E}-2$ & $3,04 \mathrm{E}-4$ & $2,17 \mathrm{E}-4$ & $1,55 \mathrm{E}-4$ & $1,33 \mathrm{E}-4$ & $9,01 \mathrm{E}-5$ & $5,67 \mathrm{E}-5$ \\
\hline $1-1$ & 1840 & $6,12 \mathrm{E}-2$ & $1,51 \mathrm{E}-2$ & $2,01 \mathrm{E}-3$ & $1,13 \mathrm{E}-3$ & $8,08 \mathrm{E}-4$ & $5,77 \mathrm{E}-4$ & $4,95 \mathrm{E}-4$ & $2,52 \mathrm{E}-4$ \\
\hline $1-2$ & 3840 & $6,69 \mathrm{E}-2$ & $3,29 \mathrm{E}-2$ & $1,87 \mathrm{E}-3$ & $1,16 \mathrm{E}-3$ & $8,47 \mathrm{E}-4$ & $5,83 \mathrm{E}-4$ & $5,09 \mathrm{E}-4$ & $2,34 \mathrm{E}-4$ \\
\hline $2-1$ & 2050 & $5,07 \mathrm{E}-2$ & $2,82 \mathrm{E}-2$ & $1,83 \mathrm{E}-3$ & $1,45 \mathrm{E}-3$ & $7,03 \mathrm{E}-4$ & $6,18 \mathrm{E}-4$ & $5,23 \mathrm{E}-4$ & $2,55 \mathrm{E}-4$ \\
\hline $2-2$ & 3150 & $7,95 \mathrm{E}-2$ & $4,36 \mathrm{E}-2$ & $2,16 \mathrm{E}-3$ & $1,67 \mathrm{E}-3$ & $7,31 \mathrm{E}-4$ & $6,62 \mathrm{E}-4$ & $5,18 \mathrm{E}-4$ & $2,71 \mathrm{E}-4$ \\
\hline $3-1$ & 3680 & $7,34 \mathrm{E}-2$ & $3,78 \mathrm{E}-2$ & $2,86 \mathrm{E}-3$ & $1,91 \mathrm{E}-3$ & $1,81 \mathrm{E}-3$ & $7,97 \mathrm{E}-4$ & $6,96 \mathrm{E}-4$ & $3,20 \mathrm{E}-4$ \\
\hline $3-2$ & 1400 & $1,22 \mathrm{E}-1$ & $6,07 \mathrm{E}-2$ & $3,45 \mathrm{E}-3$ & $2,13 \mathrm{E}-3$ & $1,74 \mathrm{E}-3$ & $8,41 \mathrm{E}-4$ & $7,19 \mathrm{E}-4$ & $3,57 \mathrm{E}-4$ \\
\hline
\end{tabular}

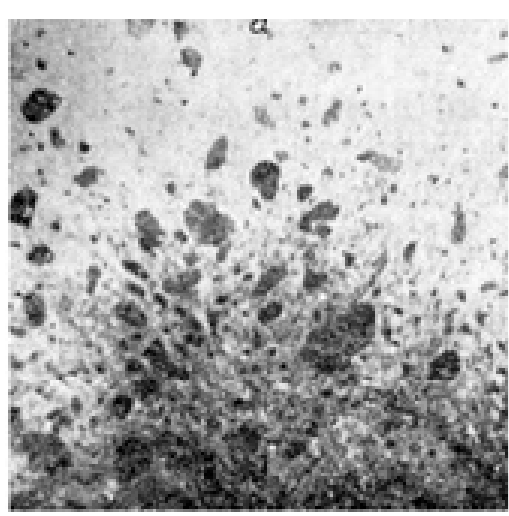

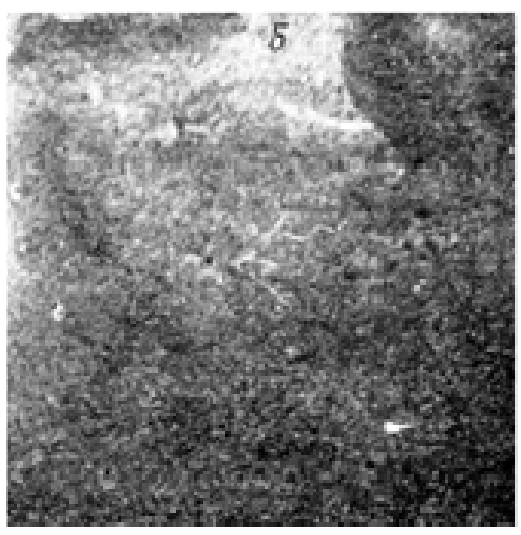

b

Fig. 6 - The structure of a cement paste bar (W/C $=0.5$, cement M300): $a$ - without cavitation treatment (bending strength $R_{b}=3,6 \mathrm{MPa}$, compressive strength $-R_{c}=17.3 \mathrm{MPa}$ ); $b-t_{\text {treat. }}=60 \mathrm{sec}$. (relative cavitation index $\left.\chi / \alpha=0.34, R_{b}=9.6 \mathrm{MPa}, R_{c}=38.1 \mathrm{MPa}\right)$

surface energy of particles. By destroying a soft primary aluminate coarse structure it is possible to obtain a fine-grained structure of cement paste, the strength of which increases by 2-3 times (Fig. 6) as compared with preparing the solution in a conventional mixer.

The "needle" structure of cement paste is formed during the treatment of laitance. It changes the course of the crystal-chemical reaction of hardening concrete, and plays the role of centers of directional solidification, which leads on the one hand, to the emergence of the fibrillary structure of cement paste, and on the other, to the emergence of hardening structural-oriented supramolecular structure.

\section{Conclusions}

The main result of the research is the ability to use the cavitation technology for waste management of the nuclear fuel cycle effectively in order to protect the environment from radioactive contamination, including: 
1. A method for the destruction of the components of pulp in the process of erosion of sludge with solutions based on cavitation-activated water, which provides an increase in the rate of sludge dissolution and volumes, is offered. It was established experimentally that the use of cavitation-activated water can increase the yield of sparingly soluble components of the pulp up to $56.03 \%$ (for $\mathrm{Al}$ ), and up to $60.72 \%$ (for $\mathrm{SiO}_{2}$ ) compared to conventional processing (35.6\% and $34.39 \%$ respectively). Using cavitation technologies in recycling nuclear power complex wastes allows uniform extracting the components of the pulp, avoiding the accumulation of fissile materials and reducing the corrosion load on structural elements of the storage;

2. The average heat transfer coefficient is experimentally determined for the entire cooling surface of the barrel container for storing the cement compound that was found to be 9.86 watts $/ \mathrm{m}^{2} \mathrm{xK}$, which is almost twice as big as the value calculated using the well-known criterion equation;

3. A substantial temperature gradient along the cross section of the barrel in the process of the heat exchange with the environment during long-term storage due to the release of heat from the radioactive decay of radionuclides contained in cement compound, can occur when values are $q_{v}=1000 \mathrm{~W} / \mathrm{m}^{3}$ or more;

4. The thermal calculation of a radioactive waste container for the long-term storage in case of cementing insoluble sludge of pulps extracted from the storage tanks can be made on the proposed numerical model with sufficient accuracy for engineering calculations in the process of cement compound hardening in a barrel with $\mathrm{W} / \mathrm{B} \geq 0,5$;

5. The data obtained in compounding of spent nuclear fuel support the results of the works $[11,12]$ being their logical continuation. Thus, we obtained an overall confirmation of a significant effect of cavitation activated water on the characteristics of cement compound during its preparation. Using cavitation technology effects is expedient in case of radiochemical production waste treatment. It also increases the strength of cement compound and improves its characteristics: freeze resistance and the rate of radionuclide leaching from cement matrix. The latter characteristic is one of the main factors determining the reliability of the long-term storage and disposal of radioactive waste.

\section{References}

[1] Агентство по ядерной энергии. Организация экономического сотрудничества и развития. Безопасность ядерного топливного цикла. М.: ЦНИИАТОМИНФОРМ, 2002. 196. [The OECD Nuclear Energy Agency.The Safety of the Nuclear Fuel Cycle. Moscow, TSNIIATOMINFORM, 2002. 196 (in Russian)].

[2] Демиденко Т.Д., Кулагин В.А., Шокин Ю.И. Моделирование и вычислительные технологии распределенных. Новосибирск: Наука, 2012, 424 с. [Demidenko N.D., Kulagin V.A. \& Shokin Iu.I. Modeling and computational technology of distributed systems. Novosibirsk, Nauka, 2012, 424 p. (in Russian)].

[3] Демиденко Т.Д., Кулагин В.А., Шокин Ю.И., Ли Ф.Ч. Тепломассообмен и суперкавитация Новосибирск: Наука, 2015, 436 с. [Demidenko N.D., Kulagin V.A., Shokin Iu.I. \& Lee F.Ch. Heat-mass exchange and supercavitation. Novosibirsk, Nauka, 2015, 436 p. (in Russian)].

[4] Федеральный закон от 21.11.95 N 170-FZ (ред. от 02.07.2013 с изменениями, вступившими в силу 02.09.2013) «Об использовании атомной энергии» [Federal law dated November 21, 
1995, No. 170-FZ “On nuclear energy use" (revised on July 2, 2013 with amendments which entered into force on September 2, 2013; in Russian)].

[5] Ивченко В.М., Кулагин В.А., Немчин А.Ф. Кавитационная технология. Красноярск, КГУ, 1990, 200 с. [Ivchenko V.M., Kulagin V.A. \& Nemchin A.F. Cavitation technology. Krasnoyarsk, KGU, 1990, 200 p. (in Russian)].

[6] Ключников А.А., Пазухин Е.М., Шигера Ю.М., Шигера В.Ю. Радиоактивные отходы АЭС и методы обращения с ними. Киев, Ин-т проблем безопасности АЭС, 2005, 487 c. [Kliuchnikov A.A., Pazukhin E.M., Shigera Iu.M. \& Shigera V.Iu. Radioactive waste of NPP and treatment methods. Kiev, Institut problem bezopasnosti AES NAN Ukrainy, 2005, 487 p. (in Russian)].

[7] Козин О.А. Методы и средства повышения экологической безопасности обращения с отходами ядерно-энергетического иикла. Красноярск, СФУ, 2011, 19 с. [Kozin O.A. Methods and means of improving the environmental safety of nuclear power cycle waste management. Extended abstract of Ph.D. Dissertation in Engineering Science. Krasnoyarsk, SibFU, 2011, 19 p. (in Russian)].

[8] Козин О.А., Кулагина Т.А. Извлечение осадков на предприятиях по переработке отработавшего ядерного топлива. Химическое и нефтегазовое машиностроение, 2010, 10, 7-15 [Kozin O.A. \& Kulagina T.A. Sludge extraction at spent nuclear fuel processing plants. Chemical and Petroleum Engineering, 2010, 10, 7-15 (in Russian)].

[9] Кулагина Т.А., Козин О.А. Разработка экоэффективных способов утилизации отходов радиохимических производств. Безопасность жизнедеятельности, 2010, 11, 31-38 [Kulagina T.A. \& Kozin O.A. Development of eco-efficient ways of recycling of radiochemical production waste. Bezopasnost' zhiznedeiatel'nosti, 2010, 11, 31-38. (in Russian)].

[10] Кулагина Т.А., Козин О.А., Матюшенко А.И. Экологическая безопасность техносферных объектов. Красноярск: Гротеск, 2015, 323 с. [Kulagina T.A., Kozin O.A. \& Matiushenko A.I. Environmental safety of technospheric objects. Krasnoyarsk, Grotesk, 2015, 323 p. (in Russian)].

[11] Кулагина Т.А., Попков В.А. Метод обращения с отходами ядерного топлива в атомной энергетикею Журнал СФУ. Техника и технологии, 2015 8(2), 198-207 [Kulagina T.A. \& Popkov V.A. The method of nuclear fuel waste management in nuclear power industry. J. Sib. Fed. Univ. Eng. technol., 2015, 8(2), 198-207 (in Russian)].

[12] Кулагина Т.А., Попков В.А. Влияние кавитационно активированной воды на характеристики цементного компаунда Журнал СФУ. Техника и технологии, 2015, 8(3), 362-368 [Kulagina T.A. \& Popkov V.A. The influence of cavitationally activated water on characteristics of cement compound. J. Sib. Fed. Univ. Eng. technol., 2015, 8(3), 362-368 (in Russian)].

[13] Кузнецов В.М. Основные проблемы и современное состояние предприятий ядернотопливного ичикла Российской Федерации. М.: Российская демократическая партия «Яблоко», 2002, 259 c. [Kuznetsov V.M. The main problems and the current state of nuclear fuel cycle facilities of the Russian Federation. Moscow, Rossiiskaia Demokraticheskaia Partiia "Iabloko", 2002, 259 (in Russian)].

[14] Лебедев В.М. Ядерно-топливный цикл. М.: Энергоатомиздат, 2005, 305 с. [Lebedev V.M. Nuclear fuel cycle. Moscow, Energoatomizdat, 2005, 305 (in Russian)].

[15] Павлов К.Ф., Романков П.Г., Носков А.А. Примеры и задачи по курсу процессов и аппаратов химической технологии. Ленинград: Химия, 1987, 576 с. [Pavlov K.F., Romankov P.G. 
\& Noskov A.A. Examples and tasks for the course of chemical technology processes and devices. Leningrad, Khimiia, 1987, 576 p. (in Russian)].

[16] Публикация 103 Международной комиссии по радиащионной защите (MKRZ), пер. с англ. М.Ф.Киселев и Н.К.Шандала. М.: Алана, 2009, 344 с. [Publication of the 103rd International Commission on Radiological Protection (ICRP). Moscow, Alana, 2009, 344 p. (in Russian)].

[17] Санитарные правила обращения с радиоактивными отходами (СПОРО -2002). SP 2.6.6.1168-02.СПб., 2003, 64 с. [Sanitary Regulations of Radioactive Waste Management (SRRWM2002) SR 2.6.6.1168-02]. St. Petersburg, Dean, 2003, 64 p. (in Russian)].

[18] Шведов В.П., Седов В.М., Рыбальченко И.Л., Власов И.Н. Ядерная технология. М.: Атомиздат, 1979, 536 c. [Shvedov V.P., Sedov V.M., Rybal'chenko I.L. \& Vlasov I.N. Nuclear technology. Moscow, Atomizdat, 1979, 536 p. (in Russian)].

[19] Вишневский Ю.Г., Гуцалов А.Г., Гордон Б.Г. Безопасность России. Правовые социально-экономические и научно-технические аспекты. М.: Знание, 2003, 400 c. [Vishnevskii Iu.G., Gutsalov A.G. \& Gordon B.G. The safety of Russia. Legal, socio-economic and scientifictechnical aspects. Regulation of Nuclear and Radiation Safety. Moscow, MGF “Znanie”, 2003, 400 p. (in Russian)].

[20] Волков В.Г., Чесноков А.С. Радиоактивные отходы: хранение и переработка. Промышленные ведомости, 2011, 11, 12 [Volkov, V.G. \& Chesnokov, A.S. Radioactive waste: storage and processing. Promyshlennye vedomosti, 2011, 11, 12 (in Russian)]. 